\title{
ASSESSING THE IMPACT OF BANKING EFFICIENCY, OPERATIONS AND REGULATION ON BANKING PERFORMANCE: FRESH INSIGHT USING DYNAMIC CORRELATED FRAMEWORK ON THE DATA SET OF RUSSIA AND UKRAINE
}

\author{
Aamir Aijaz Syed \\ Shri Ramswaroop Memorial University, India
}

\begin{abstract}
The purpose of this study is to investigate how banking industry-specific variables like regulation, efficiency, and operations affected nonperforming loans (NPLs) in Ukraine and Russia from 1995 to 2019. This study has employed the robust unit root test and cross-sectional dependencies technique along with a new DCCE approach. The dynamic correlated method is employed as it provides the best results when data suffers from cross-sectional dependencies. The study concludes that loose credit policy and lower profitability help in rising NPLs. However, in the context of macroeconomic variables, volatile interest rates and exchange rate fluctuations are the main reason for NPLs in Russia and Ukraine.

The research work also highlights the issue of cross-sectional dependencies and provide substantial methods to resolve the problem of cross-sectional dependencies and provide robust results. Findings will help policymakers to recognize the relevance of industry-specific variables in managing NPLs along with other macroeconomic variables.
\end{abstract}

Keywords: nonperforming loans, banking, PMG, unit root, cross-section dependency

DOI: http://dx.doi.org/10.15549/jeecar.v8i1.514

\section{INTRODUCTION}

Banks play a prominent role in the economic development of a country by providing adequate investment and credit opportunities (Petkovski \& Kjosevski, 2014). Banks of most countries are suffering from the issue of NPLs, which are those loans which fail to repay principal and interest. Higher portfolio of NPLs affects banking performance and credit disbursement, which leads to lower consumption and investment levels in the economy (Stiglitz 1981; Stijepović, 2014). The economic development of a country depends upon the stability and sustainability of the banking structure. However, increased competition and financial autonomy have created pressure on banking businesses. Targetbased banking and the need for credit creation has resulted in bad management practices, leading to ineffective decisions, faulty customer documentation, and finally ending up with NPLs.

Banks in Russia and Ukraine are also facing the issue of NPLs. The average of problem loans in both the countries stands more than the world average of 6.88 percent (World Development Indicators (FB.AST.NPER.ZS), 2019). In both 
countries, the portion of the corporate loan is much higher than the retail loans, as reported by the Central Bank of Russia and the National Bank of Ukraine. To revive the banking system and economic fundamentals, since 2016 host of reforms were introduced by both countries, like exchange rate reforms, inflation targeting, banking mergers, infusion of capital, and revocation of banking license (Financial development report, International Monetary Fund, 2019; Kichurchak, M.,2019). The International Monetary Fund suggested that due to the COVID-19 pandemic, both countries will face a recession in the near future, coupled with lower employment and consumer demand, which will eventually create a negative effect on debt service capabilities and banking profitability. Thus, based on all the above reasons for banking and economic disturbance, Ukraine and Russia have been considered as the sample country to study.

Previous studies have highlighted that sometime NPLs rise because of poor management decisions, ineffective policies like loan waiver schemes, and excessive credit flow (Salas \& Saurina, 2002; Berger \& DeYoung, 1997). Based on the theoretical background of the 'bad management hypothesis' as suggested by previous work, this study focuses on investigating how banking activities like operations, efficiency, and regulation affect NPLs, so that findings can be used for framing a suitable strategy for the future.

This study is novel and will help researchers, academicians, and policymakers in the following ways: first, this study contributes to the previous work of 'bad management hypothesis' by empirically investigating how banking variables like efficiency, regulations, and operations affect banking NPLs in Ukraine and Russia. Second, this study uses the new theoretical DCCE approach, which considers cross-sectional dependency of time series data and provides robust results. Third, the sample countries used in the study are also unique as the banks in these countries share a considerable amount of nonperforming loans ratio out of their total loans. These countries will also add a new region to previous literature; last, the period of study is relevant because, as the world is facing the issue of coronavirus and banks are the only source that can help in easing out the slow growth, thus studying banking variables in the current situation will add substantially toward the previous literature on NPLs.

\section{LITERATURE REVIEW}

There are various studies on investigating the determinants of NPLs, but this section of the paper will only focus on analyzing the banking determinants of NPLs.

Berger and DeYoung (1997), and Keeton and Morris (1987), conducted some of the leading studies on bank-specific determinants of nonperforming loans. They concluded that the lack of sufficient capital, profit motives, and inefficient management strategies are the main reasons behind NPL's growth in the United States. A study on the Spanish banking sector conducted by (Jimenez and Saurina, 2003), also supported the findings of (Berge and DeYoung, 1997; Keeton and Morris, 1987). The study further concluded that loose credit policies during the expansionary phase of the economy resulted in higher NPLs.

Podpiera and Weill (2008) focused his study on the Czech banking sector from 1994-2005 and suggested that bad management is the main reason for NPLs in the Czech banking sector. Further, his study concluded that regulatory capital and cost efficiency help in reducing NPLs. $\mathrm{Hu}$, Li, and Chiu, (2004) conducted a similar study focusing on the Taiwan banking sector and concluded that the size of the banks and credit disbursement policies affect NPLs significantly. Rajan and Dhal (2003) further supported the same findings in the context of the Indian banking sector.

Using a dynamic approach Espinoza and Prasad (2010), explored banks of GCC countries from 1995-2008. The findings conclude that the rate of interest spread charged by banks and lenient credit policy affects banking NPLs significantly. A study conducted by Nkusu (2011) among 26 advanced countries using impulsive response techniques also supports the above findings. Nkusu (2011) further added that management efficient decision making helps in reducing nonperforming loans to an extent. Ozili (2018) performed a study focusing on the level of financial development and financial 
liberalization and assessing its impact on NPLs in six regions of the world, using sensitivity analysis. The findings of the study concluded that the level of financial development and the presence of foreign banks positively affect NPLs. Chaibi and Ftiti, (2015) supported the above findings besides adding that leverage and inefficiency are also important determinants of NPLs in the German and French banking industry.

Swamy (2012) investigated the role of bankspecific determinants in the Indian banking industry, covering the period from 1997-2009. Using the autoregressive distribution lag method study, he concluded that profitability and loans to deposit rates are positively related to NPLs, whereas bank size is negatively associated with problem loans. Castro (2013) further substantiated the above work in context to GIPSI countries. Other studies that have evaluated the bank-specific determinants of NPLs ( Vovchak et.al., 2019; Sobolieva-Tereshchenko et.al., 2020). Most of the studies have concluded that bank poor management practices, lower management productivity, credit policies, and bank size have a significant impact on the NPLs.

The literature review section shows that although there are various studies on bankspecific determinants and NPLs, yet they suffer some of the other limitations. First, all the above studies were focused on the country or regionspecific findings and have ignored the role of cross-sectional dependencies. Thus, this new correlated model will add substantially toward previous literature. Second, most of the above studies have taken all industry and economic variables together, therefore, making it necessary to study the impact of both the variables separately. Finally, there is no conclusive study in Russia and Ukraine that focuses on the broad parameters of regulation, efficiency, and operation, thus, providing a suitable literature gap.

\section{Theoretical background}

The literature review shows that previous studies have used various models and variables. In earlier studies, determinants of nonperforming loans are categorized into two broad categories-macroeconomic determinants and bank or industry-specific determinants.
Therefore, to evaluate the bank-specific determinants of NPLs, this study has used the theoretical background of the bad management theorem and too big to fail syndrome. Both the models argued that lower-efficiency, poor business decisions, lower-cost efficiency, lowerincome, and regulations are the key factors that impact organizational productivity as given by Berger and De-Young, (1997) and Ghosh (2015). Thus, to reconfirm both the above theories, this study has tried to check the role of banking efficiency, regulation, and operation on the banking performances concerning NPLs based on following hypothesis.

- $\mathrm{H}_{0}$ : Bank efficiency has a negative impact on NPLS

- $\mathrm{H}_{1}$ : Banking Regulation has a negative impact on NPLS

- $\mathrm{H}_{2}$ : Banking Operations has a positive impact on NPLS

\section{RESEARCH METHODOLOGY AND ANALYSIS}

To study how industry-specific variables affect banking performance in Ukraine and Russia, the annual percentage change data have been taken from 1995-2019, using the statistical database of the International Financial Statistic and World Bank indicators. Due to the lack of data constraints, other industries or bank-specific variables are not included. The following proxies are considered, based on the review of previous literature and, according to various government working papers. Return on assets for banking efficiency (Abdioglu \& Aytekin, 2016), capital adequacy for measuring banking regulations (Boudriga et al., 2010), credit to deposit ratio for banking operation (Kjosevski \& Petkovski, 2014) and for measuring banking performances, nonperforming loans as a proxy variable (Syed \& Aidyngul, 2020). Interest rates and exchange rates are included in this study to make it more comprehensive (Tanasković \& Jandrić, 2015). The below table shows the detail of the data source and variables. 
Table 1: Variables Description

\begin{tabular}{|c|c|c|}
\hline Variable & $\begin{array}{c}\text { Variable } \\
\text { description }\end{array}$ & Data Source \\
\hline NPL & $\begin{array}{l}\text { Nonperforming } \\
\text { Loans }\end{array}$ & $\begin{array}{l}\text { International } \\
\text { Financial } \\
\text { Statistic (IMF) }\end{array}$ \\
\hline ROA & $\begin{array}{l}\text { Return on } \\
\text { Assets }\end{array}$ & WB indicators \\
\hline CAR & $\begin{array}{l}\text { Capital } \\
\text { Adequacy Ratio }\end{array}$ & WB indicators \\
\hline CDR & $\begin{array}{l}\text { Credit Deposit } \\
\text { Ratio }\end{array}$ & WB indicators \\
\hline INT & Interest Rate & WB indicators \\
\hline EXH & $\begin{array}{l}\text { Exchange rate } \\
\text { variation in } \\
\text { terms of USD. }\end{array}$ & WB indicators \\
\hline
\end{tabular}

\section{Unit root and cross-sectional dependency test}

Most of the studies have suggested that panel data face the issue of cross-sectional dependency because of unobserved elements and different country-specific situations, which results in idiosyncratic dependencies. Earlier studies like Levin et al. (2002) and Pesaran (2007) have employed those methods which have either ignored the above issue or were based on crosssectional homogeneity. Thus, to avoid this issue and to prevent rejection of the null hypothesis on homogeneity, this research work has employed the unit root test proposed by Pesaran (2004).

$\alpha_{i t}=\gamma_{i}+\beta_{i t} c_{i t}+\mu_{i t}$

Eq.1 is used to examine cross-sectional dependencies.

$H_{0}=s_{i z}=s_{z i}=\operatorname{Cor}\left(\mu_{i t}, \mu_{i t},\right)=0$ for $\mathrm{i} \neq z$

$H_{1}=s_{i z}=s_{z i}=\operatorname{Cor}\left(\mu_{i t}, \mu_{i t}\right) \neq 0$ for some $\mathrm{i} \neq z(3)$

$H_{0}=$ No Cross-sectional dependencies, $H_{1}=$

Data suffers from Cross-sectional dependencies.

\section{Testing of Cointegration}

Previous studies have suggested that for empirical or statistical analysis, numerous cointegration techniques are available. Researchers have always scrutinized cointegration techniques based on the duration of the data (Perron, 1991). To avoid the issue of structural break and to evaluate the long term association, this paper has used the bootstrap cointegration model, as proposed by Westerlund and Edgerton (2007). This model is appropriate for a short duration of data as it observes the lead-lag length. This feature is not available in other standard cointegration techniques like Hansen. The following equation represents the bootstrap cointegration model (Westerlund \& Edgerton, 2008).

$$
\begin{aligned}
& \Delta y_{i t}=\delta e_{t}+\alpha_{i}\left(y_{i, t-1}-\beta i^{\prime x_{i, t-1}}\right)+ \\
& \sum_{j=-q i}^{q i} a_{i j} \Delta y_{i, t-1}+\sum_{j=-q i}^{q i} \gamma_{i j} \Delta x_{i, t-1}+e_{i, t}
\end{aligned}
$$

The stated Eq4. represents endogenous variables relationship for the different datasets and subscripts $t$ and $i$ depicts time and crosssection.

\section{Dynamic Correlated Effect approach}

A review of previous literature shows that most studies have given much importance to homogenous slopes rather than cross-sectional effects. Most of the panel data analysis tools like generalized methods of moments, random, and fixed effect, give misleading results because they ignore homogeneity and consider only intercept changes. Therefore, heterogeneous coefficient with cross-sectional units has become a point of discussion among many scholars.

Various studies have given relevance to crosssectional dependencies among the data (Meo et al., 2020). Due to the issue of cross-sectional dependency, Chudik and Pesaran (2015b) introduced a new DCCE model. In this model 4 principles are used that are MG estimation, PMG estimation, CCE estimation, given by Shin et al. (1999); Pesaran and Smith (1995); and Pesaran (2006), along with using the estimation technique of Chudik and Pesaran (2015a). This model is more robust as it considers both crosssectional dependencies along with heterogenous and homogenous coefficients by considering the means and lag of cross-sectional data. This approach is also suitable for data that suffers from the issue of structural break and has a small sample size with an unbalanced panel. This study has used the equation given by Chudik and Pesaran (2015b). 


$$
\begin{gathered}
N P L_{i t}=\partial_{i} N P L_{i t-1}+\delta x_{i t}+\sum_{p=0}^{p_{t}} \gamma_{x i p} X_{t-p} \\
+\sum_{p=0}^{p_{t}} \gamma_{y i p} Y_{t-s}+\mu_{i t}
\end{gathered}
$$

NPL represents nonperforming loans, $\delta x_{i t}$ represents independent variables, $p_{t}$ shows lag limit in the cross-sections, and $\partial_{i} N P L_{i t-1}$ depicts the lag of NPL as an independent variable.

Table 2. Descriptive Statistics

\begin{tabular}{|l|l|l|l|l|l|l|}
\hline & \multicolumn{1}{|c|}{ CAR } & \multicolumn{1}{c|}{ CDR } & EXH & INT & NPL & ROA \\
\hline Mean & 16.07 & 108.02 & 20.69 & 2.81 & 16.45 & .08 \\
\hline Median & 15.8 & 108.37 & 16.85 & 1.63 & 13.14 & 1.70 \\
\hline Maximum & 20.90 & 200.18 & 67.06 & 37.9 & 54.50 & 11.12 \\
\hline Minimum & 11.20 & 20.20 & 1.47 & - & 2.40 & -22.03 \\
\hline Std. Dev & 2.97 & 34.67 & 18.48 & 14.04 & 13.26 & 6.44 \\
\hline Skewness & -0.01 & -0.17 & 1.08 & -1.11 & 1.09 & -2.45 \\
\hline Kurtosis & 1.70 & 4.45 & 3.45 & 8.18 & 3.53 & 9.03 \\
\hline Jarque-Bera & 3.36 & 4.48 & 9.84 & 7.32 & 10.10 & 12.13 \\
\hline Probability & 0.186 & .105 & .074 & .068 & .0612 & .0721 \\
\hline
\end{tabular}

\section{FINDINGS AND DATA ANALYSIS}

Keeping into consideration the issue of crosssectional dependencies and misleading results, this study has employed the cross-sectional dependency test, as given by Pesaran (2004), which focuses on the pertinent issue of crosssectional dependency. By using the pairwise correlated Ordinary Least Square technique, this test helps in selecting the most significant generation of tests suitable in the case of crosssectional dependencies (Syed, 2020). The below table 3 shows the results of the cross-sectional dependency test and descriptive analysis.

The findings of Table 3 clearly show that the data is suffering from the issue of cross-sectional dependency because the probability is less than five percent level of significance, meaning the null hypothesis needs to be rejected based on Pvalue. This study has used both first and second generations of the test, along with Augmented Dicky Fuller(ADF) test for robustness, attached as annexure 1, under which the first generation of the test assumes data homogeneity, and the other one considers cross-sectional dependency, to avoid misleading results (Chang, 2004 \& Kahia et al., 2016). The below table shows the outcomes of the First Generation of the test

Table 3: Results of Cross-sectional Dependency test

\begin{tabular}{|l|l|l|}
\hline & \multicolumn{1}{|c|}{$\begin{array}{c}\text { Cross- } \\
\text { sectional Test }\end{array}$} & \multicolumn{1}{|c|}{$\begin{array}{c}\text { Probability } \\
\text { value }\end{array}$} \\
\hline NPL & 5.21 & $0.0001^{*}$ \\
\hline ROA & 7.13 & $0.0001^{*}$ \\
\hline CAR & 5.34 & $0.0000^{*}$ \\
\hline CDR & 9.14 & $0.0001^{*}$ \\
\hline INT & 8.12 & $0.0000^{*}$ \\
\hline EXH & 11.22 & $0.0000^{*}$ \\
\hline
\end{tabular}

* at 1 percent significance level. 
Table 4: Results of Levin and Shin test

\begin{tabular}{|l|l|l|l|l|l|l|l|l|}
\hline & \multicolumn{4}{|c|}{ Levin Lin and Chu test } & \multicolumn{4}{c|}{ Pesaran Shin- Wat } \\
\hline & \multicolumn{2}{|c}{ (Levels) } & \multicolumn{2}{c|}{$\left(1^{\text {st }}\right.$ Difference $)$} & \multicolumn{2}{c|}{ (Levels) } & \multicolumn{2}{c|}{$\left(1^{\text {st }}\right.$ Difference) } \\
\hline & Stats & P-value & Stats & P-value & Stats & P-value & Stats & P-value \\
\hline NPL & -0.66 & .25 & -4.37 & $.0000^{*}$ & -0.13 & .4451 & -3.14 & $.0008^{*}$ \\
\hline ROA & 4.49 & .07 & -8.93 & $.0000^{*}$ & 2.11 & .9826 & -11.25 & $.0000^{*}$ \\
\hline CAR & -0.42 & .33 & -4.85 & $.0001^{*}$ & -0.85 & .1952 & -4.45 & $.0000^{*}$ \\
\hline CDR & -2.60 & $.00^{*}$ & -2.20 & $.0000^{*}$ & -1.75 & .0394 & -2.05 & $.0000^{*}$ \\
\hline INT & -4.09 & $.00^{*}$ & -5.60 & $.0000^{*}$ & -4.40 & .0742 & -6.67 & $.0000^{*}$ \\
\hline EXH & 2.28 & .98 & -4.75 & $.0001^{*}$ & 1.75 & .9597 & -4.35 & $.0000^{*}$ \\
\hline
\end{tabular}

* at 1 percent significance level

The results of Table 4 show that except for credit deposit and interest rate, all variables are of the first order of integration. For reconfirmation of the findings, this research work has also used a 2nd generation test called a CIPS test (Pesaran 2007), which is appropriate for the issue of cross-sectional dependencies. Results of the CIPS test show interest rate is integrated at the level, whereas all others are of the first order of integration.

Table 5. Results of CIPS test

\begin{tabular}{|l|l|l|}
\hline & Levels & $\mathbf{1}^{\text {st }}$ Difference \\
\hline NPL & .42 & $-3.14^{*}$ \\
\hline ROA & -1.13 & $-3.25^{*}$ \\
\hline CAR & -2.32 & $-3.13^{* *}$ \\
\hline CDR & -3.18 & $-6.14^{*}$ \\
\hline INT & $-1.06^{* *}$ & $-2.48^{*}$ \\
\hline EXH & -1.12 & $-3.12^{* *}$ \\
\hline
\end{tabular}

* shows the different significance levels ${ }^{*} 1$ percent, ${ }^{* *} 5$ percent

Unit root test findings show that the variables are of mixed order of integration, and none of the variables is of the second order of integration. Based on the favorable result of unit root, this study moves forward with checking the longterm association among the variables using the new dynamic correlated model. However, before using DCCE analysis, long-run cointegration is checked by using Pedroni and Westerlund Error Correction Model. Westerlund and Edgerton (2008) pointed out that most cointegration techniques like Hansen etc. ignore structural breaks, which often give spurious results; therefore, the ECM cointegration approach is employed as it considers the issue of heteroskedasticity, structural-breaks, serial correlation, and cross-sectional slopes. Table 6 and Table 7 shows the results of ECM cointegration techniques (Pedroni and Westerlund). 
Table 6. Results of Pedroni Test of Cointegration

\begin{tabular}{|c|c|c|c|c|}
\hline & t-statistic & Probability & Weight t-statistic & Probability \\
\hline \multicolumn{5}{|c|}{$\mathrm{H}_{1}$ : Within Dimension (Common Coefficient) } \\
\hline V-Stats & -0.089 & .53 & -0.14 & 0.55 \\
\hline Rho-Stats & .66 & .74 & 0.91 & 0.82 \\
\hline PP-Stats & -1.39 & .08 & -1.26 & 0.39 \\
\hline ADF- Stats & -1.47 & .06 & -0.44 & $0.02^{*}$ \\
\hline \multicolumn{5}{|c|}{ H1: Between Dimension( Individual Coefficients) } \\
\hline Rho-stats & 1.53 & 0.03 & & \\
\hline ADF-stats & -0.11 & 0.45 & & \\
\hline PP- Stats & -0.10 & 0.45 & & \\
\hline
\end{tabular}

* 5 percent Significance level

The Pedroni cointegration test results confirm that the null hypothesis of no cointegration cannot be rejected, as in six outcomes the probability value is more than a five percent significance level. Thus, to reconfirm the result of Pedroni, the Westerlund ECM cointegration test is also used. Table 7 describes the findings of ECM cointegration, which shows that banking regulation, operation, efficiency, and performance have a long-run relationship as in all cases, the probability value is less than 5 percent level of significance, meaning an alternative hypothesis to be accepted.

Table 7. Results of ECM Cointegration

\begin{tabular}{|l|l|l|}
\hline & Value & Robust P-value \\
\hline $\mathrm{Gt}$ & -4.1412 & $.0001^{*}$ \\
\hline $\mathrm{Ga}$ & -18.273 & $.0000^{*}$ \\
\hline $\mathrm{Pt}$ & -8.129 & $.0001^{*}$ \\
\hline $\mathrm{Pa}$ & -18.141 & $.0000^{*}$ \\
\hline
\end{tabular}

* 1 percent level of significance

The results of the PMG model state that interest rate, exchange rate, returns on assets, and credit deposit ratio have a significant association with NPLs, as the probability value is less than 5 percent level of significance. Interest rates and credit deposits have a direct impact on
NPLs, whereas the return on assets and exchange rates have an indirect impact on NPLs. Results of PMG estimates are re-checked by using the DCCE approach, as PMG ignores the issue of crosssectional dependency. Table 9 shows the results of the DCCE model.

Table 8. PMG test result

\begin{tabular}{|l|c|l|}
\hline $\begin{array}{l}\text { Independent } \\
\text { variable }\end{array}$ & Coefficient & $\begin{array}{l}\text { Probability- } \\
\text { Value }\end{array}$ \\
\hline CDR & 0.17 & $0.0000^{*}$ \\
\hline CAR & -0.13 & 0.0726 \\
\hline ROA & -0.24 & $0.0000^{*}$ \\
\hline INT & 0.08 & $0.0513^{*}$ \\
\hline EXH & -0.20 & $0.0013^{*}$ \\
\hline C & 22.12 & $0.0043^{*}$ \\
\hline
\end{tabular}

* 5 percent significance level

The result of the dynamic correlated model confirms that the credit to deposit ratio (a proxy variable of operations), exchange rate, and interest rate have a direct and significant association with NPLs (as the coefficient shows a positive sign and the probability value is less than 5 percent). The return on assets (a proxy for efficiency) and capital adequacy ratio (a proxy for regulations) have an indirect and significant 
association with NPLs in the panel data of Russia and Ukraine (as the coefficient shows a negative sign and the probability value is less than 5 percent). In the case of Russia, data clearly show that over the years, the banking credit cycle witnessed considerable growth from 67 percent in 1995 to 112 percent in 2018. However, regulatory capital has shown a significant drop from 20.9 percent in 2009 to 12 percent in 2018, resulting in the growth of NPLs in Russia. Ukraine also shares a similar situation with a rise in the banking credit cycle over the years and subsequent drop in the regulatory capital and thus contributing toward NPLs. So, it can be concluded that the statistical analysis of the data fully supports the findings of this study.

Table 9. Findings of Dynamic Correlated Model

\begin{tabular}{|l|l|l|}
\hline $\begin{array}{c}\text { Independent } \\
\text { variable }\end{array}$ & Coefficient & $\begin{array}{c}\text { Probability- } \\
\text { Value }\end{array}$ \\
\hline $\mathrm{NPL}(-1)$ & -0.05 & $0.0320^{* *}$ \\
\hline CDR & 0.33 & $0.0001^{* *}$ \\
\hline CAR & -.15 & $0.0010^{*}$ \\
\hline ROA & -0.28 & $0.0001^{* *}$ \\
\hline INT & 0.12 & $0.0200^{* *}$ \\
\hline EXH & 0.21 & $0.0040^{* *}$ \\
\hline
\end{tabular}

* 1 percent significance level, ${ }^{* *} 5$ percent significance level

The Findings of the DCCE model will be considered for final results, as the coefficient value is more than the PMG estimate. Additionally, the DCCE model is more robust in the case of cross-sectional dependency. The findings of the study also strengthen the work of Ozili (2018) and Beck et.al (2015).

\section{CONCLUSION AND DISCUSSION}

This research work focuses on investigating the impact of various banking parameters like regulation, efficiency, and operation on banking performance in Ukraine and Russia by employing a new DCCE framework. This study significantly contributes toward the theoretical literature by discussing the cross-sectional dependency issue of time series panel data, besides highlighting the role of three significant parameters of the banking industry.

The result of the study shows that lenient credit policy, inadequate regulatory capital, lower profitability, exchange rate disturbances, and abrupt interest rate fluctuation are the main reasons that result in increasing banking NPLs. Therefore, it can be concluded that poor credit disbursement policies, lower profitability due to inefficient operations, and the lack of sufficient regulatory capital that provide stability are the crucial reasons affecting banking performance in Ukraine and Russia.

The findings suggest that the banking industry of Russia and Ukraine should pay more attention to non-interest income and promote the profitability of banks through effective banking strategies and also by scrutinizing loan quality and recovery mechanisms. Banks having lower profits resort to excessive credit distribution without proper documentation of borrowers' creditworthiness, which often results in loan defaults. The banking system in Ukraine and Russia also lacks an effective credit recovery mechanism, leading to higher loan default. Therefore, based on the findings, the banking industry of Ukraine and Russia should focus more on other banking businesses like underwriting, share market operations, digitalized payment portals avenues, financial instrument trading, and other financial services instead of relying only on credit deposit spread. Based on reports from the World Bank and the International Monetary Fund, public sector banks constitute roughly 60 percent of the banking industry in Ukraine and Russia, which shows their disproportionate dependence on public sector organizations. Scrutiny of corporate lending also seems imperative for a healthier and more profitable banking sector to discourage bank owners and corporations from using loans for personal gains.

According to a report by the World Bank, the COVID-19 situation could plunge the Central and Eastern European region into a dire economic recession. Banks should, therefore, proactively focus on tackling the impending economic turbulence and the likely surge of loan defaults resulting from high unemployment rates and persistent lockdown. The government should also focus on other macroeconomic 
determinants like interest rate and exchange rate as they also substantially contribute to NPLs in Russia and Ukraine. The use of artificial intelligence (AI) and machine learning approach in keeping a watch on the frequent defaulter will also help in reducing NPLs. Digitalization and techniques of artificial intelligence can help in the preparation of early warning techniques and loan workout strategies. Banks can use automated systems for tracking small loans and industrial expert opinions for large loans. One of the surveys conducted by AI Opportunity Landscape research shows that around 15 percent of venture funding in banking-related artificial intelligence is for finding lending solutions Allen et al.,(2020). So the bank in Russia and Ukraine can also use the same AI and machine learning approach in reducing and tracking NPLs.

Last, based on the findings, it can also be concluded that the results of this study fully support the theoretical background of bad management and too big to fail syndrome.

\section{LIMITATIONS AND IMPLICATIONS}

Since only two countries are from Central and Eastern Europe, hence it serves as a limitation. This study also suggests that scholars may also consider other variables like the level of financial intermediation and development for studying their impact on NPLs in the coming future. Apart from focusing on accessing the role of banking and macroeconomic determinants, this study also emphasizes the issue of cross-sectional dependency along with providing suggestive methods to tackle such issues while dealing with time-series data.

\section{REFERENCES}

ABDİOĞLU, N., \& AYTEKİN, S. (2016). Takipteki Kredi Oranını Etkileyen Faktörlerin Belirlenmesi: Mevduat Bankaları Üzerinde Bir Dinamik Panel Veri Uygulaması. Issletme Araştırmaları Dergisi, 8(1), 538-555.

Allen, F., Gu, X., \& Jagtiani, J. (2020). A Survey of Fintech Research and Policy Discussion.

Beck, T., \& Brown, M. (2015). Foreign bank ownership and household credit. Journal of Financial Intermediation, 24(4), 466-486.
Berger, A.N., and R. DeYoung, (1997). Problem loans and cost efficiency in commercial banks. Journal of Banking \& Finance, 21(6): 849-870.Available at: https://doi.org/10.1016/s03784266(97)00003-4.

Boudriga, A., Taktak, N. B., \& Jellouli, S. (2010, September). Bank specific, business and institutional environment determinants of banks nonperforming loans: evidence from mena countries. In Economic Research Forum, Working Paper(Vol. 547, pp. 1-28).

Castro, V. (2013). Macroeconomic determinants of the credit risk in the banking system: The case of the GIPSI. Economic Modelling, 31, 672-683.

Chaibi, Hasna, and Zied Ftiti, (2015). "Credit risk determinants: Evidence from a crosscountry study". Research in International Business and Finance 33: 1-16

Chang Y, (2004). î Bootstrap Unit root tests in panels with cross-sectional dependency î. $J$ Econ 120:263-293

Chudik A, Pesaran MH (2015b). Common correlated effects estimation of heterogeneous dynamic panel data models with weakly exogenous regressors. JEcon 188(2):393-420

Chudik, A, and M. H. Pesaran (2015a). Large panel data models with cross-sectional dependence: A survey. In The Oxford Handbook Of Panel Data, ed. B. H. Baltagi, 245. Oxford: Oxford University Press

Espinoza, R., and A. Prasad, (2010). Nonperforming Loans in the GCC Banking Systems and their Macroeconomic Effects, IMF Working Paper 10/224 (Washington: International Monetary Fund).

Jimenez, G. \& Saurina, J. (2003). "Loan characteristics and credit risk," Proceedings 857, Federal Reserve Bank of Chicago.

Ghosh, A. (2015). Banking-industry specific and regional economic determinants of nonperforming loans: Evidence from US states. J. Financ. Stab., 20, 93-104. [CrossRef]

$\mathrm{Hu}, \mathrm{J}, \mathrm{Li}, \mathrm{Y}$, and Chiu, Y(2004). "Ownership and non-performing loans: Evidence from Taiwan's banks"e, The Developing Economies, Vol. 42, No.3, pp. 405-420 
Kahia M, Aïssa MSB, Charfeddine, L (2016). Impact of renewable and non-renewable energy consumption on economic growth: new evidence from the MENA Net Oil Exporting Countries (NOECs). Energy 116:102-115

Keeton, W.R., and C.S. Morris, (1987). Why do banks' loan losses differ? Economic Review, 72(5): 3-21.

Kichurchak, M. (2019). Bank deposit activity in Ukraine: Directions and factors of development activation. Journal of Eastern European and Central Asian Research (JEECAR), 6(1), 145-160. https://doi.org/10.15549/jeecar.v6i1.275

Levin A, Lin CF, Chu CSJ (2002). Unit root test in panel data: Asymptotic and finite sample properties. J Econ 108:1-24

Meo S, Saeed S., Aria. H, Nazar, R(2020). Water resources and tourism development in South Asia: An application of dynamic common correlated effect (DCCE) model, Environmental Science, and Pollution Research, 3, 2020.DOI: 10.1007/s11356-01008361-8

Nkusu, M., (2011). "Non-performing loans and macro-financial vulnerabilities in advanced economies", IMF Working Paper 11/161.

Ozili, P. K. (2018). Impact of digital finance on financial inclusion and stability. Borsa Istanbul Review, 18(4), 329-340.

Perron P (1991). Test consistency with varying sampling frequency. Econometric Theory 7(3):341-368

Pesaran MH (2006). Estimation and inference in large heterogeneous panels with a multifactor error structure. Econometrica 74(4):967- 1012

Pesaran MH (2007). A simple panel unit root test in the presence of cross-section dependence. J Appl Econ 22:265-312

Pesaran MH, Smith R (1995). Estimating longrun relationships from dynamic heterogeneous panels. JEcon 68(1):79-113

Pesaran, M. Hashem (2004). General diagnostic tests for cross-section dependence in panels' IZA Discussion Paper No. 1240

Petkovski, M., Kjosevski, J. (2014). Does Banking Sector Development Promote Economic
Growth? An Empirical Analysis for Selected Countries in Central and South-Eastern Europe. Economic Research, 27(1), 55-66. DOI:10.1 080/1331677X.2014.947107

Podpiera, J., Weill, L., (2008). "Bad luck or bad management? Emerging banking market experience," J. Finance. Stab. 4, pp 135-148.

Rajan, R., \& Dhal, S. C. (2003). Non-performing loans and terms of credit of public sector banks in India: An empirical assessment. Reserve Bank of India Occasional Papers, 24(3), 81-121.

Salas, V. and J. Saurina, (2002). Credit risk in two institutional regimes: Spanish commercial and savings banks. Journal of Financial Services Research, 22(3): 203-224.

Shin Y, Pesaran MH, Smith RP (1999). Pooled mean group estimation

Sobolieva-Tereshchenko, O., \& Zhukova, Y. (2020). Stress testing the banking systems: Approach of Ukraine. Journal of Eastern European and Central Asian Research (JEECAR), 72), 205-218. https://doi.org/10.15549/jeecar.v7i2.358

Stiglitz, J., \& Weiss, A. (1981). Credit Rationing in Markets with Imperfect Information. The American Economic Review, 71(3), 393-410.

Stijepović, R. (2014). Recovery and Reduction of Non-Performing Loans - Podgorica Approach. Journal of Central Banking Theory and Practice, 3(3): 101-108. DOI: 10.2478/jcbtp-2014-0017

Swamy, V. (2012). "Impact of macroeconomic and endogenous factors on non-performing bank assets", The International Journal of Banking and Finance, Vol.9, No.1, pp.27-47

Syed, A.A. (2020). “Does Banking Efficiency, Regulation, and Operations Affect Banking Performance in South Asia: Dynamic Correlated Model Approach". Front. Appl. Math. Stat. 6(38). DOI: 10.3389/fams.2020.00038

Syed, A. A., \& Aidyngul, Y. Macro economical and bank-specific vulnerabilities of nonperforming loans: A comparative analysis of developed and developing countries. Journal of Public Affairs, e2414.

Tanasković, S., Jandrić, M. (2015). Macroeconomic and Institutional 
Determinants of Non-performing Loans. Journal of Central Banking Theory and Practice, 2015/1:47-62. DOI: 10.1515/jcbtp2015-0004

Vovchak, O., Reverchuk, S., Rudevska, V., \& Khlan, Y. (2019). Bank business modelling and levels of non-performing loans:

Perspectives of international risk factors in Ukraine. Journal of Eastern European and Central Asian Research (JEECAR), G(2), 282296.

https://doi.org/10.15549/jeecar.v6i2.391

Westerlund J, Edgerton DL (2007). A panel bootstrap cointegration test. Econ Lett 97(3):185-190

Westerlund J, Edgerton DL (2008). A simple test for cointegration independent panels with structural breaks. Oxf Bull Econ Stat 70(5): 665-704

Finance \& Development, International Monetary Fund, March 2019, Vol. 56, No. 1. International Monetary Fund, Global Financial Stability Report, 2020

World Bank, Data Views from 10.03.2014, www.data.worldbank.org/indicator/FB.AST. NPER.ZS

Annexure 1: Augmented Dicky Fuller test result.

\begin{tabular}{|l|l|l|l|l|}
\hline & \multicolumn{2}{|c|}{ Levels } & \multicolumn{2}{c|}{$1^{\text {st }}$ Difference } \\
\hline & Stats & P-value & Stats & P-value \\
\hline NPL & -0.25 & .08 & -2.14 & $.0000^{*}$ \\
\hline ROA & 1.26 & $.03^{*}$ & -4.15 & $.0000^{*}$ \\
\hline CAR & -0.12 & .13 & -3.16 & $.0000^{*}$ \\
\hline CDR & -1.25 & $.02^{*}$ & 1.13 & $.0000^{*}$ \\
\hline INT & -2.19 & $.01^{*}$ & -2.15 & $.0000^{*}$ \\
\hline EXH & 1.13 & .16 & -1.67 & $.0000^{*}$ \\
\hline
\end{tabular}

* 5 percent level of significance.

\section{ABOUT THE AUTHORS}

Aamir Aijaz Syed, email: aamirank@gmail.com

Dr. Aamir Aijaz Syed is an Assistant professor, Department of Managements, Shri Ramswaroop Memorial University, India. 